\author{
dr hab. Agnieszka LESZCZYŃSKA \\ Wydział Ekonomiczny, Uniwersytet Marii Curie-Skłodowskiej \\ e-mail: agnieszka.leszczynska@poczta.umcs.lublin.pl
}

DOI: $10.15290 /$ ose.2016.04.82.03

\title{
NIERÓWNOWAGA RELACJI A KSZTAŁTOWANIE ZRÓWNOWAŻONEGO ŁAŃCUCHA DOSTAW
}

\begin{abstract}
Streszczenie
W artykule podjęto problem nierównowagi relacji w kształtowaniu zrównoważonego łańcucha dostaw (SSC). Analiza relacji kupujacy-dostawca została przeprowadzona z wykorzystaniem analizy studium przypadku łańcuchów dostaw branży spożywczej. Wykazała ona, że występująca przewaga wymusza osiaganie zgodności z wymaganiami rozwoju zrównoważonego (SD). Cele i inicjatywy SD są określane w sposób arbitralny, a ich koszty oraz ryzyko przerzucane na dostawców. Z perspektywy zarządzania organizacjami praca przyczynia się do lepszego zrozumienia wpływu nierównowagi na wdrażanie rozwoju zrównoważonego.
\end{abstract}

Słowa kluczowe: zrównoważony łańcuch dostaw, asymetria relacji, nierównowaga

\section{IMBALANCE RELATIONSHIPS AND SUSTAINABLE SUPPLY CHAIN}

\section{Summary}

The paper is concerned with the problem of imbalance in supply chain relations in the forming of a sustainable supply chain. Analysis of the purchaser-supplier relationship is conducted with the use of the case study method. It shows that the presence of an advantage enforces compliance with the requirements of sustainable development. The objectives and initiatives of SD are determined in an arbitrary way, but their costs and risks are transferred to suppliers. From a management perspective, the paper contributes to a better understanding of the influence of imbalance on implementing sustainable development.

Key words: sustainable supply chain, relationship asymmetry, imbalance

JEL: Q01, L60

\section{Wstęp}

Literatura dotycząca rozwoju zrównoważonego postrzega organizacje jako zakorzenione w sieci powiązań z interesariuszami [Porter, 2006]. Wzajemne oddziaływania organizacja - otocznie powoduja, że rozwój zrównoważony (SD) organizacji nie może być 
osiagnięty bez uwzględnienia wpływu i rezultatów także łańcucha dostaw [Paulraj, 2011]. Nie jest możliwe ograniczenie oddziaływania środowiskowego wyrobów z pominięciem wpływu ogniw łańcucha. Tym samym w odniesieniu do wdrażania SD jest konieczna zmiana optyki z indywidualnej na sieciowa [Sarkis i in. 2011]. Przekonanie to prowadzi do koncepcji zrównoważonego łańcucha dostaw (SSC), która zakłada, że przedsiębiorstwa powinny osiagać ekonomiczne, społeczne i ekologiczne cele w całym łańcuchu dostaw, a także podejmować wspólną realizację inicjatyw w obszarze SD [Seuring, 2010, s. 2]. Carter, Rogers [2008] zdefiniowali SSC jako strategiczna, transparentna integrację i osiaganie celów dzięki koordynacji kluczowych procesów biznesowych dla doskonalenia długookresowych wyników ekonomicznych. Zrównoważony łańcuch dostaw wymaga traktowania dostawców jako strategicznych partnerów w relacji równorzędności [Vachon, Klassen, 2006; Pagell, 2009]. Jednak w praktyce $z$ uwagi na pozycje przetargową kupującego występuje nierównowaga (asymetria władzy). Nierównowaga relacji, wynikająca $\mathrm{z}$ asymetrii władzy, była już przedmiotem badań w odniesieniu do łańcuchów dostaw [Sanzo i in. 2007; Gulati, Sytch, 2007]. Andersen, Larsen [2009] wskazali, że dominujące organizacje posiadają możliwość kontrolowania praktyk społecznych dostawców. Pedersen zauważył trudność wpływania kupującego na dostawców, jeżeli posiada on słabsza pozycję przetargowa. Badania Hall [2000] potwierdziły to, że władza stanowi czynnik wpływający na zdolność organizacji do wdrażania odpowiedzialnych praktyk. Niniejsza praca wykorzystuje dorobek uprzednich badań poświęconych problematyce SSC [Casciaro, Piskorski, 2005], niemniej przyczynia się do lepszego zrozumienia tego, w jaki sposób przewaga organizacji oddziałuje na wdrażanie SD przez postrzeganie tych działań jako bazujących na relatywnej asymetrii relacji kupujacy - dostawca.

\section{Nierównowaga relacji w łańcuchu dostaw}

Zależności w łańcuchu dostaw mogą być rozpatrywane w dwóch wymiarach: 1) nierównowagi władzy, asymetrii zależności; 2) wzajemnej zależności [Yilmaz i in. 2005]. Asymetria relacji pojawia się, kiedy firma A jest w większym stopniu zależna od firmy B, niż B od A. Koncepcyjnie, przewaga jednej organizacji skutkuje korzyściami ekonomicznymi dla niej, lecz powoduje dysfunkcjonalne i nieproduktywne relacje w sieci. Odwołując się do teorii dominacji przedsiębiorstw, należy zauważyć, że elementem generującym nierównowage jest władza (siła). Wynika ona nie tylko ze struktur rynkowych (udziału, wyróżnienia się na rynku) czy z kompetencji i zasobów, ale z różnych efektów: wpływu, pociagania, dominacji i absorpcji, jakie przedsiębiorstwa moga wywierać na inne jednostki. Granicą przedsiębiorstwa jest opór innych przedsiębiorstw. Według Pfeffer, Salancik [1978], Porter [1979], można wyróżnić następujące układy sił występujące w relacjach międzyorganizacyjnych:

- wzajemną niezależność,

- nierównorzędną niezależność,

- wzajemną zależność,

- nierównorzędną zależność. 
Podobny rozkład zależności przedstawili Maloni i Benton [2000], definiując władzę jako zdolność jednej firmy (określanej jako źródło) do wpływania swoimi zamiarami i działaniami na inną firmę (określaną jako obiekt). W niniejszej pracy skoncentrowano się na relacji nierównorzędnej zależności, której źródłem jest władza.

Możliwość wpływania na zachowania organizacji wymaga posiadania kontroli nad zasobami, od których inni są zależni, a do których dostęp jest konieczny celem osiagnięcia wyników [Cox, 2007]. Należy tutaj odnieść się do teorii uzależnienia od zasobów. Teoria ta wskazuje, że żadna organizacja nie jest samowystarczająca, gdyż organizacje wchodzą w relacje, żeby zapewnić sobie dostęp do zasobów [Singh i in. 2011]. W ten sposób wytwarza się zależność pomiędzy organizacjami, co w efekcie może generować sytuację, w której jedna organizacja wywiera nacisk na drugą [Kurczewska, 2011]. W przypadku nierównowagi dominująca organizacja podejmuje działania, by podtrzymać swoja przewagę. Może działać oportunistycznie [Ireland, Webb, 2007], faworyzować własne interesy, zachęcać dostawców do podejmowania inwestycji [Cox, 2007]. Związki długookresowe są podtrzymywane, jeżeli pozwalają na wzrost zależności od organizacji dominującej [Casciaro, Piskorski, 2005]. Natomiast występują negatywne zjawiska dotyczące kontroli [Belaya i in. 2009], dzielenia się ryzykiem i nagrodami. Łańcuch, w którym ma miejsce nierównowaga, z reguły nie tworzy sytuacji korzystnej dla obu partnerów (typu win-win). Przyczynia się to do braku stabilizacji. Aby zjawiska te ograniczyć, poszukuje się alternatywnych kanałów zbytu, rozwija długookresowe umowy, prowadzi wspólną dyferencjację produktów.

\section{Kształtowanie zrównoważonych łańcuchów dostaw (SSC)}

Problem kształtowania SSC jest podnoszony w odniesieniu do dużych przedsiębiorstw. Posiadają one większy dostęp do zasobów i w większym stopniu są narażone na presję zewnętrzną. W efekcie częściej inicjują tworzenie SSC.

Pierwszym etapem w tym procesie jest ocena przygotowania organizacji i zrozumienie otoczenia zewnętrznego. Umożliwia to: określenie priorytetów, ocenę ryzyk i szans, budowanie wewnętrznego wsparcia. National Bureau of Sustainability [Creating...] we współpracy z innymi organizacjami zestawiło działania składające się na kształtowanie SSC, a mianowicie:

- definiowanie celów dla przedsiębiorstwa,

- określenie oczekiwań dotyczących SD,

- wybór dostawców,

- ocena i rozwój dostawców,

- budowanie na podstawie uprzednich doświadczeń.

Przejście w kierunku SSC wymaga odpowiednich inwestycji, jak również znaczących zmian w kulturze organizacyjnej. Nieodzowne jest przeformułowanie relacji z innymi firmami [Alvarez i in. 2010]. Dotychczasowe badania [Hejmose, 2012; Hall, 2001; Pedersen, Andersen, 2006] potwierdziły, że duże przedsiębiorstwa wpływają na zachowania dostawców, zachęcając ich do wdrażania praktyk SD [Walker, Preuss, 2008]. Przedsiębiorstwa te wywierają presję na adaptowanie kodeksu etycznego i bardziej 
zrównoważonych praktyk [Pedersen, Andersen, 2006]. Jednak badania te wymagaja dalszego uszczegółowienia. Koncentrowały się one bowiem jedynie na wybranej (wedlug kryterium wielkości) grupie przedsiębiorstw z pominięciem relacji zachodzących pomiędzy nimi.

\section{Metoda badań}

W pracy przyjęto podejście oparte na studium przypadku. Pozwoliło to na uwzględnienie czynników sytuacyjnych (w tym zależności społecznych) oraz dynamiki zmian w otoczeniu [Eisenhardt, Graebner, 2007; Barrat $i$ in. 2011]. Zamierzeniem autorki artykułu było zrozumienie relacji w łańcuchu dostaw oraz ich wpływu na SD. Na potrzeby badań wybrano dwa łańcuchy (rysunek 1.). Lańcuch 1. obejmuje część łańcucha dostaw wiodącej sieci handlowej, posiadającej ponad 300 placówek handlowych. Oferuje ona produkty około 1 tys. dostawców. Większość z nich to małe firmy zatrudniające do 50 osób. Tym samym promuje polskich producentów i buduje gamę produktów regionalnych. Kupujący A dokłada starań, aby utrzymać standardy odpowiedzialności korporacyjnej. Wprowadzony został kodeks „Stosunki wertykalne w łańcuchu dostaw zasady dobrej praktyki”, którego celem jest popularyzowanie uczciwych praktyk handlowych. W tym łańcuchu skoncentrowano się na relacjach firmy kupującej z trzema dostawcami. Lańcuch 2. bazuje na relacjach wertykalnych niewielkiej liczby dostawców, których udziały w dostawach są znaczące. Ich więzi handlowe z kupującym są trwałe (>10 lat). Dostawcami są małe, rodzinne przedsiębiorstwa rolnicze, zatrudniające pracowników sezonowych.

\section{Schemat badanych łańcuchów dostaw}

RYSUNEK 1.

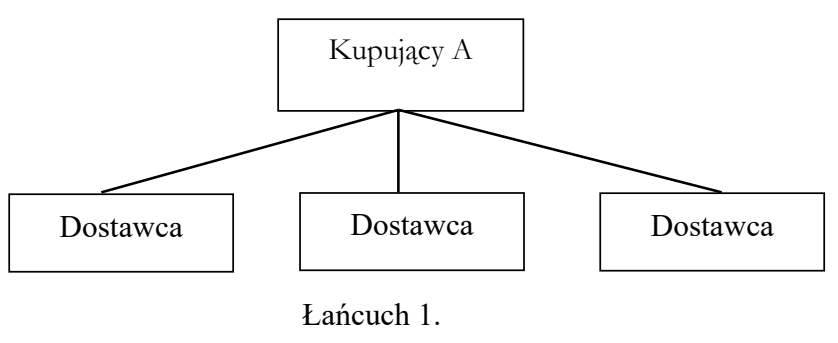

Źródło: opracowanie własne.

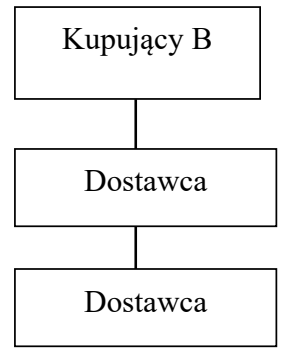

Łańcuch 2.

Badania przeprowadzono w sektorze spożywczym. Wybrany sektor charakteryzuje się niewielką liczbą dużych firm kupujących. Wpływa to na siłę przetargową odbiorcy, który może narzucać swoje warunki współpracy [Hingley, Lindgreen, 2010]. Zhu i inni [2008] wskazali, że duże przedsiębiorstwa są w większym stopniu narażone na 
presję zewnętrzną i muszą brać odpowiedzialność za zachowania etyczne dostawców. W efekcie wprowadzają standardy dotyczace postępowania etycznego i odpowiedzialności społecznej [Mollenkopf i in. 2010]. Może być to problemem dla mniejszych dostawców, którzy posiadają mniejsze umiejętności i zasoby [Pedersen, 2009]. Uprzednie badania łańcuchów dostaw w sektorze spożywczym wykazały asymetrię władzy oraz ukierunkowanie relacji na kupującego [Hingley, 2010]. Jednak nie poruszały one problematyki SD. Równocześnie działalność w sektorze spożywczym wymaga uwzględniania standardów środowiskowych i społecznych (w szczególności odnoszących się do zdrowia) [Thompson, Scoones, 2009].

Narzędzie badawcze stanowił częściowo ustrukturalizowany kwestionariusz. Wywiady trwały 0,5-1 godz. W przypadku dostawców przeprowadzono pojedyncze wywiady, u kupującego - wywiady objęły kilku pracowników. Respondentami zostali pracownicy odpowiedzialni za kwestię zakupów (A, B), rozwoju zrównoważonego (A, B) lub właściciele firm produkcyjnych, menedżerowie sprzedaży (dostawcy łańcuchów: 1., 2.).

Zastosowano pytania zamknięte i otwarte. Dotyczyły one: siły zależności, jakości relacji, rozwijania praktyk SD. W zakresie relacji skupiono się na tym: jak ważny jest dostawca dla procesu produkcyjnego (końcowej wielkości sprzedaży)? w jaki sposób relacje z nim wpływają na wyniki społeczne i środowiskowe kupującego? jaka jest pozycja przetargowa dostawcy/odbiorcy? W odniesieniu do kwestii SD poszukiwano odpowiedzi na pytania: czy w kontraktach uwzględniono wymagania SD? czy ich realizacja jest monitorowana? kto planuje nowe inicjatywy SD? kto ponosi ciężar inwestycji? jak kształtuje się rozkład kosztów/ korzyści, ryzyka w łańcuchu dostaw? Analizę wyników skoncentrowano się na: 1) równowadze/ nierównowadze relacji w łańcuchu, 2) ich wpływie na wprowadzenie SD, 3) rozkładzie kosztów/ korzyści praktyk SD. W celu zapewnienia wiarygodności badań na etapie zbierania danych pozyskano odpowiedzi od kilku respondentów, zaś pytania badawcze zaproponowano na podstawie uprzednich opracowań.

\section{Wyniki badań}

Badane łańcuchy dostaw cechuje występowanie nierównowagi między dostawcami a kupującymi. Relacje w łańcuchu 1. sa zdominowane przez firmę A. Wynika to z braku alternatywnych kanałów sprzedaży dla dostawców, co skutkuje występowaniem władzy kupującego. Potwierdzają to negocjacje cenowe i warunki kontraktów. Większość kontraktów jest odnawiana co roku, mimo że związki z dostawcami są wieloletnie. Kupujący jest niechętny zawieraniu dłuższych umów. Firma A kontroluje częściowo działania operacyjne dostawców przez przenoszenie na nich pewnych prac (mycie, przechowywanie). W badanym łańcuchu dostaw stopień zależności od kupującego jest różny. Największy występuje w przypadku przedsiębiorstw, które większość swojej produkcji sprzedają temu odbiorcy: Obecny biznes zapoczatkowany zostat przez firme A, gdzie sprzedajemy 100\% naszego towaru. Z kolei, firma A kupuje towar od wielu dostawców, co (w opinii respondentów) ma w następstwie przynieść optymalizację kosztów. Dostawcy starają się spełnić wymagania firmy A z uwagi na możliwość utraty kontraktu. Wpro- 
wadzenie dodatkowych standardów przyczyniło się do poszerzenia ich wiedzy: Wprowadzenie rozwoju zrónnoważonego w firmie $A$ zmienito nasze nastawienie do tej kwestii. (...) Myśle, ze A jest killka kroków przed nami we wprowadzaniu SD, wiec jest jakby nassym wzorcem. Dostawcy biorą udział w szkoleniach dotyczących SD. Szkolenia są realizowane w siedzibie kupującego, a mają na celu przedstawienie wymagań i standardów. W przypadku dostawców II rzędu odpowiedzialność za ich wyniki spoczywa na dostawcach wyższego szczebla.

W drugim łańcuchu dostaw zachodzi przewaga dostawcy I rzędu. Wynika ona z elastyczności wyboru kupującego - przedsiębiorstwo posiada szereg alternatyw ze względu na specyfikę produktu. We wdrażaniu koncepcji SD kupujący jest uzależniony od dostawcy. Jego współpraca warunkuje bowiem osiaganie celów SD. Dostawca I rzędu odgrywa rolę pośrednicząca. Relacje z nim decydują o przeniesieniu SD na niższe ogniwa łańcucha dostaw. Z perspektywy dostawcy pozwala to na wzrost ceny jego produktów.

Badania wykazały, że we wszystkich przedsiębiorstwach występuja aspekty środowiskowe i społeczne. Społeczne zagadnienia są związane z: warunkami pracy, wynagradzaniem, kwestiami bezpieczeństwa pracy, dyskryminacją, w szczególności pracowników sezonowych. Kwestie środowiskowe łączą się z wykorzystywaniem zasobów środowiskowych przez dostawców i obciażeniem środowiska. Kupujący staje się zależny od dostawcy w zakresie wyników środowiskowych i społecznych (tabela 1.).

\section{Przyczyny zależności w odniesieniu do SD}

TABELA 1.

\begin{tabular}{|l|l|}
\hline \multicolumn{1}{|c|}{ Zależność kupującego } & \multicolumn{1}{c|}{ Zależność dostawcy } \\
\hline Zależność od dostawcy w osiaganiu celów SD. & Brak wiedzy i umiejętności wymaganych do \\
Brak dostępu do zasobów środowiskowych. & SD posiadanych przez kupującego. \\
Brak kontroli nad zasobami społecznymi. & Brak długookresowych umów. \\
& $\begin{array}{l}\text { Brak zasobów koniecznych do realizacji in- } \\
\text { westycji ukierunkowanych społecznie i śro- }\end{array}$ \\
& dowiskowo. \\
\hline
\end{tabular}

Źródło: opracowanie własne.

W obu łańcuchach ma miejsce ewolucja relacji: Zależności żmieniaja sie we wspótzależności. Nasz kontrahent interesuje sie już nie tylko naszymi produktami, ale też dziataniami i sposobem funkcyonowania. Skutkuje to złagodzeniem nierównowagi. Dostawcy stają się bardziej świadomi swojego wpływu na wyniki całego łańcucha, jednak są zobligowani do realizacji procedur/spełnienia standardów określonych przez kupującego. Pewne driałania musza być zrobione i nie podlegaja negocjacjom. Oczekiwania SD skierowane sq do nas. (...) Ježeli chcemy być dostawca musimy iść z kuprjacym. Kupujący przyjmuje przywództwo w odniesieniu do SD. Wciażposzukuja możliwości i nonych uyzzwań i dobrze jest wspótpracować z.przedsiębiorstwem tego kalibru. Možna powiedzieé, że firma nas inspiruje. Kupujący określa cele SD. Inicjatyny sa definitymnie uymuszane na nas. (...) Dotychczas nie przeznacsylismy wiele czasu na to $(S D)$, ale musimy to zmienic. Stosowane terminy związane z SD zostały określone przez kupującego. To spotkania w jego siedzibie stają się platformą do dyskusji o SD. Doświadczenie i perspektywa dostawcy nie są uwzględniane. Niket nie pytał nas, w jaki sposób wi- 
drielibyśmy funk.jonowanie dostaw w kontekście SD. Planowanie SD odbywa się przez firmę dominująca. Formalne wymagania dotyczqce SD okerélane sa przez firme B i prayjmuja postac dodatkowych zapisów społecznych $i$ środowiskowych. Maja one charakter obligatoryjny. Przewaga kupującego powoduje zwiększenie wymagań operacyjnych dla dostawców [Hingley $\mathrm{i}$ in. 2006]. Może wiązać się z: przeprojektowaniem procesów produkcyjnych, zmianą procedur, poszerzeniem zakresu odpowiedzialności dostawcy za wyniki. Ma miejsce jednostronna komunikacja. Zagadnienia SD nie są częścią codziennej komunikacji z dostawcami. W tej sytuacji dostawcy starają się spełnić minimalny poziom wymagań. Niektóre ich działania maja charakter reaktywny. Opór wynika przede wszystkim z braku czasu i środków. Wyraźna jest także niechęć do angażowania się w przyszłe wymagania SD. Poziom zaangażowania dostawców w realizację inicjatyw SD w czasie jest zmienny. Wzrasta on w okresie kontraktowania i zakupów, po czym spada do poziomu stałego minimum. Efektywność wprowadzanych inicjatyw jest analizowana przez stronę inicjującą SD. Najczęściej przyjmuje to postać audytów emisji.

Nierównowaga relacji na korzyść kupującego umożliwia mu wprowadzenie dodatkowych wymagań dla dostawców, których spełnienie jest warunkiem pozostania w łańcuchu. Wobec tego relatywna przewaga kupującego wspiera wdrażanie SD, ponieważ: 1) pozwala na określenie wymagań dla dostawców przystępujących do łańcucha; 2) wzmacnia pozycję negocjacyjną kupującego, co wpływa na określanie standardów i wymagań dotyczących SD. Przewaga po stronie dostawcy powoduje, że możliwości wpływania na niego są ograniczone. Kupujący może wzmacniać wymagania, jedynie jeżeli jest w dobrej pozycji negocjacyjnej [Pedersen, Andersen, 2006].

W badanych łańcuchach dostaw występująca nierównowaga relacji oddziałuje na nierówny podział kosztów/korzyści z SD. Koszty prac związanych z SD oraz ryzyko są przenoszone na dostawców. My ponosimy koszty inwestycji w driałania ochrony środowiska. (...) Aby zrealizowaí cele środowiskowe, konieczne sa pewne inwestygje, ale kupujacy zrzuca je na nas. (...) Firma B poprzez swoje dzialania powieksza nasze ryzyko. W łańcuchu 2. wykorzystuje się długoterminowe umowy uwzględniające wzrost cen (Umowa zawarta na 5 lat pržewiduje każdego roku wrrost ceny o dodatkowe 5\%), w celu minimalizowania ryzyka nieosiagnięcia celów SD. Odmienną strategię zaobserwowano w łańcuchu 1., gdzie dostawcy mają ograniczone możliwości decyzyjne, zaś firma A podejmuje działania, aby utrzymać swoja przewagę. Nie dostajemy dodatkowych dochodów z angażowania sie. (...) Negocjacje cenowe nie sa powiazane z. SD. Uzyskujemy korzyśsi jedynie poprzez możliwość wyróżnienia sie spośród innych dostarczajacych. Zatem za wdrożenie SD dostawcy są wynagradzani. Część respondentów dostrzega dodatkowe korzyści z wdrożenia SD w postaci: transferu wiedzy, organizacyjnego uczenia się i budowania potencjału dla SD.

\section{Podsumowanie}

Przeprowadzone badania wykazały istnienie zjawiska nierównowagi w badanych łańcuchach dostaw. Świadczą o tym: 1) brak alternatywnych kanałów zbytu, 2) elastyczność doboru dostawców/odbiorców, 3) presja na utrzymanie stałych cen. W łańcuchu 1. inicjatorem wprowadzenia SD był kupujący, który jednostronnie zdefiniował cele SD. Zaobserwowano w nim: nierównomierne rozłożenie ryzyka, przerzucanie kosztów 
działań dostosowawczych na dostawców. Wykorzystywanie przewagi wywołuje opór dostawców i prowadzi do niepewności kupującego, czy cele SD zostaną osiagnięte. Kupujący staje się w większym stopniu zależny od dostawców, ci bowiem posiadają dostęp do zasobów środowiskowych oraz zasobów ludzkich, co wpływa na wyniki łańcucha. W badanym łańcuchu firma A stara się przeforsować swoje interesy w odpowiedzi na presję zewnętrzna. Relacje w łańcuchu przyjmują formę transakcyjna.

Z kolei, badania drugiego łańcucha pokazuja, że wielkość przedsiębiorstwa nie odgrywa roli, jeżeli chodzi o przewagę w łańcuchu dostaw. Aby zapewnić dostęp do zasobów środowiskowych, duże przedsiębiorstwa muszą wchodzić w relacje z mniejszymi organizacjami. Wskazuje to możliwość rozszerzenia teorii RDT.

Uzyskane wyniki dowodza, że poziom nierównowagi wpływa na poziom zgodności oraz zakres zaangażowania w SD. Większa przewaga kupującego generuje wyższy poziom zgodności.

Poziom przewagi kupujacego jest pozytymnie powiazany zakresem działan podejmowanych przez dostawcón w obszarze rozwoju zrónnoważonego.

W przypadku równowagi relacji dostawcy odczuwają niższą presję na spełnianie wymagań SD. Przyczynia się to do niepewności kupującego w odniesieniu do osiagania celów SD.

Przewaga dostawcy w lańcuchu dostaw negatywnie wplywa zatem na wdrażanie ro ₹uvoju zrównoważonego.

Asymetria władzy jest źródłem wdrażania SD. Jest to zgodne z uprzednimi pracami, gdzie przewaga kupującego wspiera adaptacje dostawcy [Crook, Combs, 2007; Hingley, 2005]. Uzyskane wyniki dodatkowo potwierdzają znaczenie przewagi dostawcy. W takiej sytuacji kupujący nie może w pełni kształtować praktyk dostawcy. Powoduje to nowe możliwości reagowania dla dostawców. Poziom, do którego kupujący może oddziaływać na praktyki dostawców na niższych poziomach sieci, zależy od struktury relacji. Przewaga kupującego może być zatem ograniczona jedynie do najbliższych dostawców. Wywieranie presji na kolejne, niższe ogniwa sieci jest utrudnione.

Nierównowaga relacji powoduje, że dostawcy w większym stopniu są obciążeni kosztami i ryzykiem, podczas gdy korzyści uzyskuje kupujący (tabela 2.). Wykorzystywanie przewagi przyczynia się do pogorszenia jakości relacji i komunikacji. Jeżeli odczucie to jest podzielane przez większość dostawców, wówczas w łańcuchu dostaw wzrasta opór wobec nowych inicjatyw. Stawia to pod znakiem zapytania możliwość osiagnięcia celów SD. Kupujący staje się zależny od dostawców i dostępnych dla niego zasobów. Możliwe staje się ich łączenie się przeciwko kupującemu. Zjawisku temu przeciwdziała wsparcie dostawców na wszystkich etapach wdrażania SD oraz zawieranie długoterminowych kontraktów. 
TABELA 2.

Skutki nierównowagi w łańcuchu dostaw

\begin{tabular}{|l|l|}
\hline \multicolumn{1}{|c|}{ Negatywne } & \multicolumn{1}{|c|}{ Pozytywne } \\
\hline Definiowanie celów SD & Motywowanie, inspirowanie do \\
Komunikacja & wdrożenia \\
Dostępność informacji, wyników & Przywództwo \\
dotyczących SD & Wyniki środowiskowe \\
Wybór dostawców & Wyniki społeczne \\
Ryzyko dla dostawców & Nabywanie wiedzy \\
Koszty dla dostawców & Raportowanie \\
\hline
\end{tabular}

Źródło: opracowanie własne.

Nierównowaga relacji powoduje trudności w równoważeniu celów: ekonomicznych, społecznych i środowiskowych w łańcuchu dostaw. Menedżerowie mniejszych firm powinni uświadamiać sobie odpowiedzialność za kształtowanie zrównoważonego łańcucha. Jednak trzeba zaznaczyć, że rozwój ekonomiczny małych dostawców nie jest zharmonizowany z ich rozwojem w innych obszarach. Potrzebna jest zatem ewolucja od koncentracji na wynikach ekonomicznych w kierunku SD. Zasadne jest dążenie do lepszego podziału ryzyka i korzyści w łańcuchu dostaw. Najlepsze warunki rozwoju łańcucha tworzy równowaga relacji, gdzie dostawca i kupujący polegają na sobie wzajemnie, następuje równomierne rozłożenie korzyści i zasobów [Casciaro, Piskorski, 2004]. Sytuacja równowagi relacji generuje warunki, w których SD podlega integracji [Keating i in. 2008]. Wyniki badań świadczą o wpływie nierównowagi na kształtowanie SSC. Dotyczy to przede wszystkim wyboru dostawców i budowania relacji z nimi. Łatwiej jest wprowadzać SD, jeżeli w łańcuchu zachodzi równowaga zależności lub występuje niewielka przewaga kupującego. Wówczas kupujący może odgrywać rolę przywódczą we wdrażaniu SD. Równocześnie nierównowaga nie jest zjawiskiem jednoznacznie negatywnym. W przypadku braku możliwości kontroli (operacji) dostawców, przewaga może być niezbędna do wprowadzenia praktyk SD. Jej ocena zależy od użycia/braku użycia narzędzi przymusu. Nierównowaga relacji nie jest przeszkodą w tworzeniu zrównoważonego łańcucha dostaw, jeśli są przyjmowane odpowiednie strategie.

\section{Literatura}

Alvarez G., Pilbeam C., Wilding R., 2010, Nestle Nespresso AAA sustainable quality program: An investigation into the governance dynamics in a multi-stakeholder supply chain network, "Supply Chain Management: An International Journal", 15 (2).

Andersen M., Skjoett-Larsen T., 2009, Corporate social responsibility in global supply chains, "Supply Chain Management: An International Journal", 14 (2).

Barratt M., Choi T. Y., Li M., 2011, Qualitative case studies in operations management: Trends, research outcomes, and future research implications, "Journal of Operations Management", 29 (4). 
Belaya V., Gagalyuk T., Hanf J., 2009, Measuring Asymmetrical Power Distribution in Supply Chain Networks: What Is the Appropriate Method?, "Journal of Relationship Marketing", 8 (2).

Casciaro T., Piskorski M. J., 2005, Power Imbalance, Mutual Dependence and Constraint Absorption: A Closer Look at Resource Dependence Theory, "Administrative Science Quarterly", 50.

Casciaro T., Piskorski M.J., 2004, Power imbalance and interorganizational relations: resource dependence theory revisited, Academy of Management, New Orleans, LA.

Cox A., 2007, Transactions, power and contested exchange: Towards a theory of exchange in business relationships, "International Journal of Procurement Management", 1 (1-2).

Creating a Sustainable Supply Chain - Best Practices and Business Drivers, http://spendmatters.com/.

Crook T. R., Combs J. G., 2007, Sources and consequences of bargaining power in supply chains, "Journal of Operations Management", 25 (2).

Eisenhardt K. M., Graebner M. E., 2007, Theory building from cases: opportunities and challenges, "Academy of Management Journal", 50 (1).

Gulati R., Sytch M., 2007, Dependence asymmetry and joint dependence in interorganizational relationships: Effects of embeddedness on a manufacturers performance in procurement relationships, "Administrative Science Quarterly”, 52 (1).

Hall J., 2000, Environmental supply chain dynamics, "Journal of Cleaner Production", 8 (6).

Hall J., 2001, Environmental supply-chain innovation, "Greener Management International", 35.

Hingley M., 2005, Power to all our friends? Living with imbalance in supplier-retailer relationships, Industrial Marketing Management, 34 (8).

Hingley M., Lindgreen A., 2010, Living with powver imbalance in the food supply chain, [in:] Delivering performance infood supply chains, C. Mena, G. Stevens (eds.), Woodhead Publishing, Cambridge.

Hingley M., Lindgreen A., Casswell B., 2006, Supplier-retailer relationships in the UK fresh produce supply chain, "Journal of International Food and Agribusiness Marketing", 18, no. 1-2.

Hoejmose S. U., Adrien-Kirby A. J., 2012, Socially and environmentally responsible procurement: A literature review and future research agenda of a managerial issue in the 21st century, "Journal of Purchasing \& Supply Management", 18 (4).

Ireland R., Webb J., 2007, A multi-theoretic perspective on trust and power in strategic supply chains, "Journal of Operations Management", 25 (2).

Keating B., Quazi A., Kriz A., Coltman T., 2008, In pursuit of a sustainable supply chain: insights from Westpac Banking Corporation, "Supply Chain Management: An International Journal", 13 (3).

Kurczewska U., 2011, Lobbing i grupy interesu w Unii Europejskiej: proces konsolidacji systemu, Wydawnictwo Naukowe PWN, Warszawa.

Maloni M., Benton W. C., 2000, Powver influences in the supply chain, "Journal of Business Logitics", 21 (1). 
Mollenkopf D., Stolze H., Tate W. L., Ueltschy M., 2010, Green, lean, and global supply chains, "International Journal of Physical Distribution \& Logistics Management", $40(1-2)$.

Pagell M., Wu Z., 2009, Building a more complete theory of sustainable supply chain management using case studies of 10 exemplars, "Journal of Supply Chain Management", 45 (2).

Paulraj A., 2011, Understanding the relationships between internal resources and capabilities, sustainable supply management and organizational sustainability, "Journal of Supply Chain Management", 47 (1).

Pedersen E. R., 2009, The many and the few: rounding up the SMEs that manage CSR in the supply chain, "Supply Chain Management: An International Journal", 14 (2).

Pedersen E. R., Andersen M., 2006, Safeguarding corporate social responsibility [CSR] in global supply chains: How codes of conduct are management in buyer-supplier relationships, "Journal of Public Affairs", 6 (3/4).

Pfeffer J., Salancik G., 1978, The External Control of Organizations: A Resource Dependence Perspective, Harper \& Row, New York.

Porter M., 1979, How Competitive Forces Shape Strategy, "Harvard Business Review", 57 (2).

Porter M. E., Kramer M. R., 2006, Strategy and society: The link between competitive advantage and corporate social responsibility, "Harvard Business Review", 84 (12).

Sanzo M.J., Santos M.L., Alvarez L.I., Alvzquez R., 2007, The effect of a buyer's market orientation on attitudinal loyalty toward a supplier: is dependence a moderator?, "Supply Chain Management: An International Journal", 12 (4).

Sarkis J., Zhu Q., Lai K.-H., 2011, An organizational theoretic review of green supply chain management literature, "International Journal of Production Economics", 130 (1).

Singh P. J., Power D., Chuong S. C., 2011, A resource dependence theory perspective of ISO 9000 in managing organizational environment, "Journal of Operations Management", $29(1-2)$.

Thompson J., Scoones I., 2009, Addressing the dynamics of agri-food systems: An emerging agenda for social science research, "Environmental Science \& Policy", 12 (4).

Touboulic A., Chicksand D., Walker H., 2014, Managing Imbalanced Supply Chain Relationships for Sustainability: A Power Perspective, "Decision Sciences", 45 (4).

Vachon S., Klassen R. D., 2006, Extending green practices across the supply chain: The impact of upstream and downstream integration, "International Journal of Operations \& Production Management", 26 (7).

Walker H., Preuss L., 2008, Fostering sustainability through sourcing from small businesses: Public sector perspectives, "Journal of Cleaner Production", 16 (15).

Yilmaz C., Sezen B., Ozdemir O., 2005, Joint and interactive effects of trust and [inter] dependence on relational behaviors in long-term channel dyads, "Industrial Marketing Management", 34 (3).

Zhu Q., Sarkis J., Lai K.-H., Geng Y., 2008, The role of organizational size in the adoption of green supply chain management practices in China, "Corporate Social Responsibility and Environmental Management", 15 (6). 